\title{
Online Conversations: A Semantic Network Analysis of Cultural Differences in Conversations on McDonald's Corporate Facebook Sites between Taiwan and the USA
}

\author{
Hui-Jung Chang \\ Graduate Institute of Mass Communication, Fu-Jen Catholic University, Taipei, Taiwan \\ Email: hij.chang.taipei@gmail.com
}

Received 15 February 2015; accepted 1 June 2015; published 5 June 2015

Copyright (C) 2015 by author and Scientific Research Publishing Inc.

This work is licensed under the Creative Commons Attribution International License (CC BY). http://creativecommons.org/licenses/by/4.0/

(c) (i) Open Access

\section{Abstract}

The goal of this article is to explore the manifestation of culture in language usage posted by McDonald's Facebook site operators and the accompanying replies posted by fans on the sites in Taiwan and the USA, utilizing the collectivism-individualism dimension suggested by Hofstede's model of culture. Data were gathered from the whole year of 2012 on the official McDonald's Facebook sites in the two countries. A semantic network analysis tool, Wolfpak, was used to analyze the words generated from the postings written by Facebook site operators and fans. In general, the study found support for cultural differences through word usage from official McDonald's Facebook site operators and fans between Taiwan and the USA. It appeared that Taiwanese Facebook culture is characterized with the creation of a "we-identity", with dependence more on people in authority, and a focus on money and materialism; whereas American Facebook culture is characterized with an "I-identity", with less dependence on people in authority, and more focus on self-interests.

\section{Keywords}

Collectivism/Individualism, Network Analysis, Facebook

\section{Introduction}

The emergence of social media, such as social network sites (SNSs), has facilitated conversations among users on a global scale [1]. The thoughts, opinions, and expertise exchanged on these online communication platforms 
are often as influential as many of the renowned journalist and industry experts. Thus, corporations are now recognizing and include these powerful tools of social media in their advertising and marketing communication strategies [2] [3]. However, a successful multinational corporation is required to satisfy the localization needs in its website design [4]-[6]. Localization refers to the process of providing a platform that incorporates local content and functionality [7]. The key to a successfully localized website is one that has been developed within the local culture [8]-[12].

Culture is "the collective programming of the mind that distinguishes the members of one group or category of people from another” ([13], p. 9). Within the cultural norms of each group, individuals demonstrate proper behavior in a given situation, including language usage [14]. Hofstede (2001) has suggested that language is "the most clearly recognizable part of culture" ([13], p. 21). The two most common languages on the internet are English at 27.3\% and Chinese at 22.6\% [15]. According to Hofstede's typology of culture, the culture of individuals whose official language is English is markedly different from that of those whose official language is Chinese. That is, most of the people who communicate in English belong to an individualistic culture, and most of the people who communicate in Chinese a collectivistic culture. The present study thus attempted to examine differences of language usages on Facebook, the most prevalent SNS communication tool on a global level [15], between the Chinese language and English language. The two countries chosen to study were Taiwan and the USA because Facebook is the most popular SNS in both countries, and the official languages of the two countries are Chinese and English, respectively.

Past research that has examined cultural manifestations on websites mainly focused on the differences of design interfaces such as webpage links, colors, videos, site maps and animations (e.g., [3] [9] [12] [16]-[19]); few studies have examined the differences of actual language usage on the websites across cultures. At a time when attracting Facebook fans is an important marketing communication strategy worldwide, the present paper contributes to our understanding about fans' interaction on Facebook across different cultural contexts. The goal of this article is to explore the manifestation of culture in language usage posted by McDonald's Facebook site operators and the accompanying replies posted by fans on the sites in Taiwan and the USA, utilizing the collectivism-individualism dimension suggested by Hofstede's model of culture. Data were gathered from the whole year of 2012 on the official McDonald's Facebook sites in the two countries. A semantic network analysis tool, Wolfpak, was used to analyze the words generated from the postings written by Facebook site operators and fans in Taiwan and the USA in 2012.

\section{Literature Review}

In this section, I will first discuss the concept of culture and its associations with the dimension of individualism/ collectivism. Next, past research using the dimension of individualism/collectivism to study language use on SNSs will be reviewed. Finally, semantic network analysis will be introduced and its associated research regarding language use on SNSs will be discussed. Then, research questions will be proposed at the end of this section.

\subsection{Culture and Individualism/Collectivism}

According to Hofstede (2001), culture can be defined as "the interactive aggregate of common characteristics that influence a human group’s response to its environment” ([13], p. 10). Group members of different cultures are programmed differently to guide their behaviors [20]. The collective mental programming guides group members to respond to all problems of human societies. Through extensive empirical studies, Hofstede (2001) identified five basic problems encountered by all human societies, which include power distance, uncertainty avoidance, individualism versus collectivism, masculinity versus femininity and long-term versus short-term orientation $^{1}$ [13]. Among them, the problem of individualism versus collectivism, which is mainly related to "the integration of individuals into primary groups" (p. 29), has been suggested as the major dimension of culture that reflects the most fundamental distinction between Chinese and American culture [21] and is the major dimension of culture that has been studied across disciplines to explain similarities and differences in behavior across cultures [20] [22].

\footnotetext{
${ }^{1}$ According to Hofstede (2001), power distance refers to the difference in solutions to human inequality; uncertainty avoidance refers to the level of stress facing an unknown future; masculinity versus femininity refers to the division of emotional roles between two genders; and long-term versus short-term orientation refers to the choice to focus on the teachings of Confucius (p. 29) [13].
} 
Individualism/collectivism deals with the relationship between the individual and the collectivity, which is mainly reflected in the way people live together. Although human beings are gregarious animals, different societies show different degrees of gregariousness [13]. Differences in gregariousness through the way in which individuals live with others influences the way they are socialized into their cultures, which in turn influences how they conceive of themselves [20]. In an individualistic society, where people live in nuclear families, both horizontal and vertical integration are missing between family members. Adolescent children are expected to leave the homes of their parents and only maintain necessary contact after that, while grandparents are expected to live apart from their children and lead lives of their own [13]. Thus, people raised in individualistic cultures have relatively little involvement with each other, and they expect less of others than the people in collectivistic cultures do [23]. Growing up, children in individualistic cultures learn to think of themselves as "I” [13]. This "I” identity constructs an independent self "whose behavior is organized and made meaningful, primarily by reference to one's own internal repertoire of thoughts, feelings, and actions” [24].

In contrast, in a collectivistic society, where people live in patrilineal extended families, people are integrated into dense and cohesive "we"-groups. This "we"-group or in-group consists of members of an extended family such as grandparents, aunts and cousins [13]. People depend on the in-group's protection throughout their lifetime in exchange for their loyalty [25]. Thus, children learn to think of themselves with a "we" identity [13], and even after they move into the real world of adulthood, they will not establish identities separate from that of their in-group community ([26], p. 226). This “we” identity constructs an interdependent self who is defined mainly through relationships with others, not through one's own opinions, abilities and characteristics [24]. The interdependent self is "both a center of relationships and a dynamic process of development with a network of relationships” ([14], p. 78).

\subsection{Individualism/Collectivism and Language Use on SNSs}

Little research has examined language use on SNSs from the perspective of culture, let alone from the individualism/collectivism dimension of it. Most of the extant studies examining cultural differences are in the more general area of cultural manifestations on website designs. For example, based on the gist of individualism/collectivism, past research has developed a few web page indicators to describe the degree of cultural manifestations on websites in this dimension. Since members of collectivistic cultures value the cohesiveness of in-groups and are more concerned with group membership, it has been demonstrated that collectivistic websites have more discussion forums, newsletter subscriptions, loyalty programs, and family themes such as family photos and pictures of teams of employees than those of individualistic websites [11] [16] [17] [19] [21] [27]-[29].

One study has examined the associations between culture and language use on SNSs. DeAndrea, Shaw, and Levine (2010) have studied how culture influences self-expression and self-construal by examining the language use of the "About Me” section on Facebook of 120 Facebook users representing African Americans, Caucasian Americans and ethnic Asians, respectively [30]. To their surprise, they found that the African American group demonstrated a higher proportion of independent self-expressions than Caucasian Americans and ethnic Asians, indicating larger differences between subcultures within the United States than those between western and eastern cultures.

\subsection{Semantic Network Analysis and Language Use}

In social networks, nodes refer to the actors in a network, and connections among the actors constitute the network itself. In a semantic network analysis, the nodes are the words, and the analysis will demonstrate how the words are connected to each other [31]. Semantic networks "assess the hierarchical structure among words within texts" [32]. It examines word frequency of given texts and determines the most frequently occurring words and shared words among the given texts. The words detected by semantic network analysis indicate the similarity of semantic structure [33]. For example, Fitzgerald and Doerfel's (2004) study in customer complaint letters of a financial institution identified that the financial institution suffered from problems involving both their visa products and their checking accounts by detecting a cluster of words such as visalog checks, problem and checking [32]. Also, Kim’s (2012) semantic network analysis of nanotechnology industry websites in South Korea found out that the main focus of the nanotechnology industry is the development and application of nanotechnology by detecting the most shared words across the websites which are control, developing, device, material, molecular, nanometer, nanotechnology, and science [34]. 
In addition, Doerfel and Connaughton (2009) used semantic network analysis to study the structure of the content of US presidential debates held between 1964 and 2004 and found out that electoral winners often used more tightly clustered groups of words or concepts than the losers [31]. For example, in the Kennedy versus Nixon debate, Kennedy demonstrated a more coherent theme for a better America by using words such as United States, means-better-America, growth, and security; while Nixon used words such as first, point, far, and concerned, which demonstrated a losing theme. Another study by Lee, Kim and Rosen (2009) identified the main research theme by examining the ComAbstracts in the area of new media and Internet research between 1991 and 2005 using semantic network analysis [35]. They found two major research themes during the sampling years: social aspect (social, public, organizations, groups, influence, people and relations), and issue-based and policy agendas (issues, disclosure, knowledge, policy, process, health).

The extant study has not yet examined the structure of the content of Facebook postings, from fans or from site operators using a semantic network analysis. This paper attempts to identify the words used across postings on McDonald's Facebook sites in Taiwan and the USA, respectively; and examine whether there are cultural differences in the words used between the two countries. Based on Hofstede's model, Taiwan belongs to a more collectivistic culture and the USA to a more individualistic culture. However, previous studies have questioned the distinct classification of the two countries in the collectivistic-individualistic dimension. For example, Chang and Tseng's study (2009) has suggested that the USA demonstrates higher levels of collectivism than Taiwan after examining the content of users' photos used in social networks sites in the two countries (Taiwanese websites featured less group photos than American sites) [36]. The other study conducted by Kim and Yun (2008) also found that the social interaction on Cyworld, the most popular social network site in South Korea, another collectivistic culture based on Hofstede' classification, is characterized with individualism [37].

Accordingly, the following research question is proposed:

Will language usage (site operators and fans) on McDonald's Facebook site in Taiwan reflect a higher level of collectivism than McDonald's Facebook site in the USA?

\section{Method}

\subsection{Sampling and Procedure}

The official McDonald's Facebook site in Taiwan (https://www.facebook.com/mcdonalds.tw) and in the USA (https://www.facebook.com/McDonalds) were selected, respectively. All the postings written by McDonald's Facebook site operators and fans in both countries during the 12-month period in 2012 were collected in April and May 2013. After initial scrutinizing, the content of the postings categorized as postings that: a) contained video or pictures only with no text; b) contained only page links with no text; and c) were spam messages were excluded from further analysis. There were a total of 80 and 34 messages generated by McDonald's Taiwanese Facebook site operators and McDonald's American Facebook site operators respectively; and a total of 8342 and 44,145 messages generated by Taiwan's Facebook site fans and the USA's Facebook site fans, respectively, in this sampling period.

\subsection{Analysis}

Wolfpak, a semantic network analysis software program [38], was used to calculate the language usage patterns and to display graphical representations of the fan networks. This program was chosen because it is the only semantic network analysis software program available at this point that can identify both Chinese and English characters at the same time.

The initial scrutinizing of the postings showed that the majority of the postings contained around 60 words in the message content. Thus, in order to see more of an overall pattern of language usage on Facebook sites, postings were aggregated on a monthly interval. As a result, there were 12 sets of sub data from Taiwan's Facebook site, and 10 sets of sub data from the USA's Facebook site (no postings were written from either site operators or fans in February and June). To facilitate a more accurate analysis of language usage between the two countries, three categories of words were excluded from the original data set before they were analyzed by Wolfpak. These words included a) prepositions such as in, at, on, to; b) conjunctions such as "and”, or; and c) articles such as “a” and "the”. Each set of data was analyzed by Wolfpak individually. Then, each set of data was aggregated on a 3-month and 6-month interval, respectively to be analyzed by Wolfpak. Due to the data capacity of Wolf- 
pak, the overall interpretation of all 12 datasets was made by this researcher by aggregating the analysis produced by monthly, quarterly and semi-yearly Wolfpak outputs.

\section{Results}

Two types of outputs by Wolfpak were used for the present analysis: the distribution of word frequency and graphical presentation of words' structure. Figure 1 and Figure 2 demonstrated the two types of outputs for Taiwanese data while Figure 3 and Figure 4 displayed the two types of outputs for American data. Overall, the semantic network analysis performed on the present dataset detected some differences in the postings on Taiwan and the USA's McDonald's Facebook sites in terms of the frequency of the words used. It appears that the postings written by either site operators or fans on Taiwan's Facebook site demonstrated a higher level of collectivism than those postings on the USA's Facebook site. Below, the findings are listed resulting from postings written by site operators and fans in both countries.

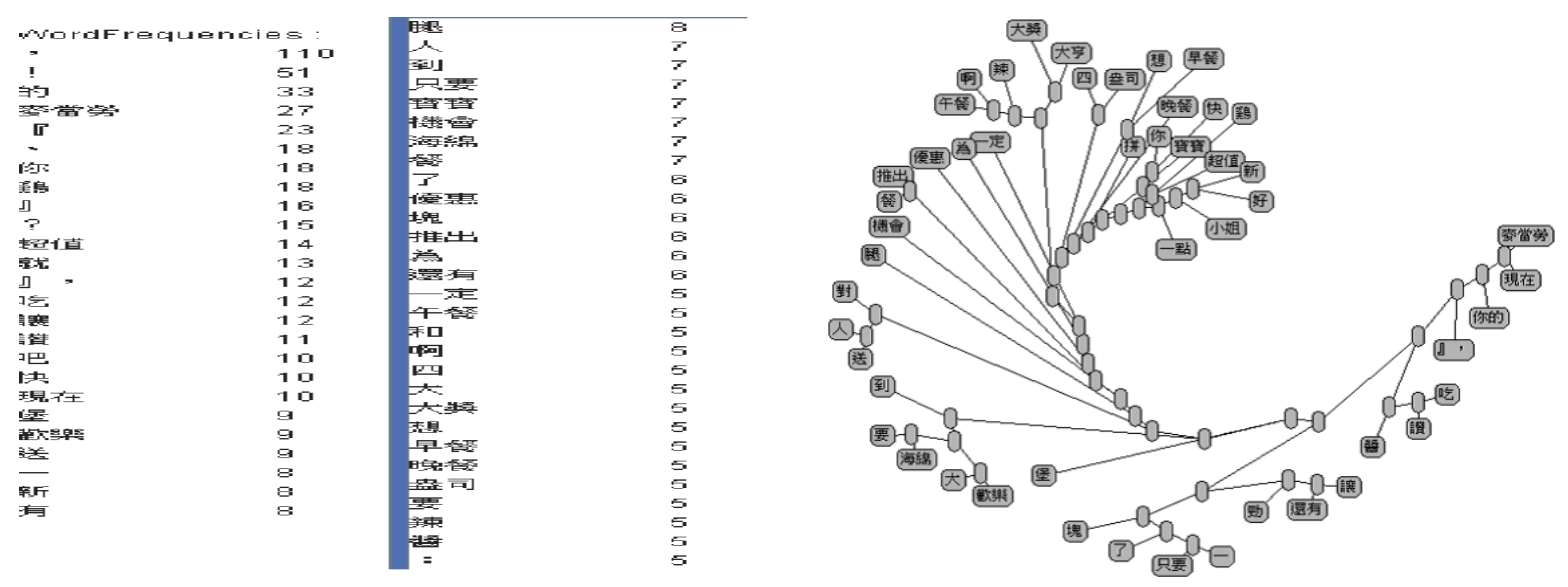

Figure 1. Wolfpak outputs of Taiwanese operators from January to June.

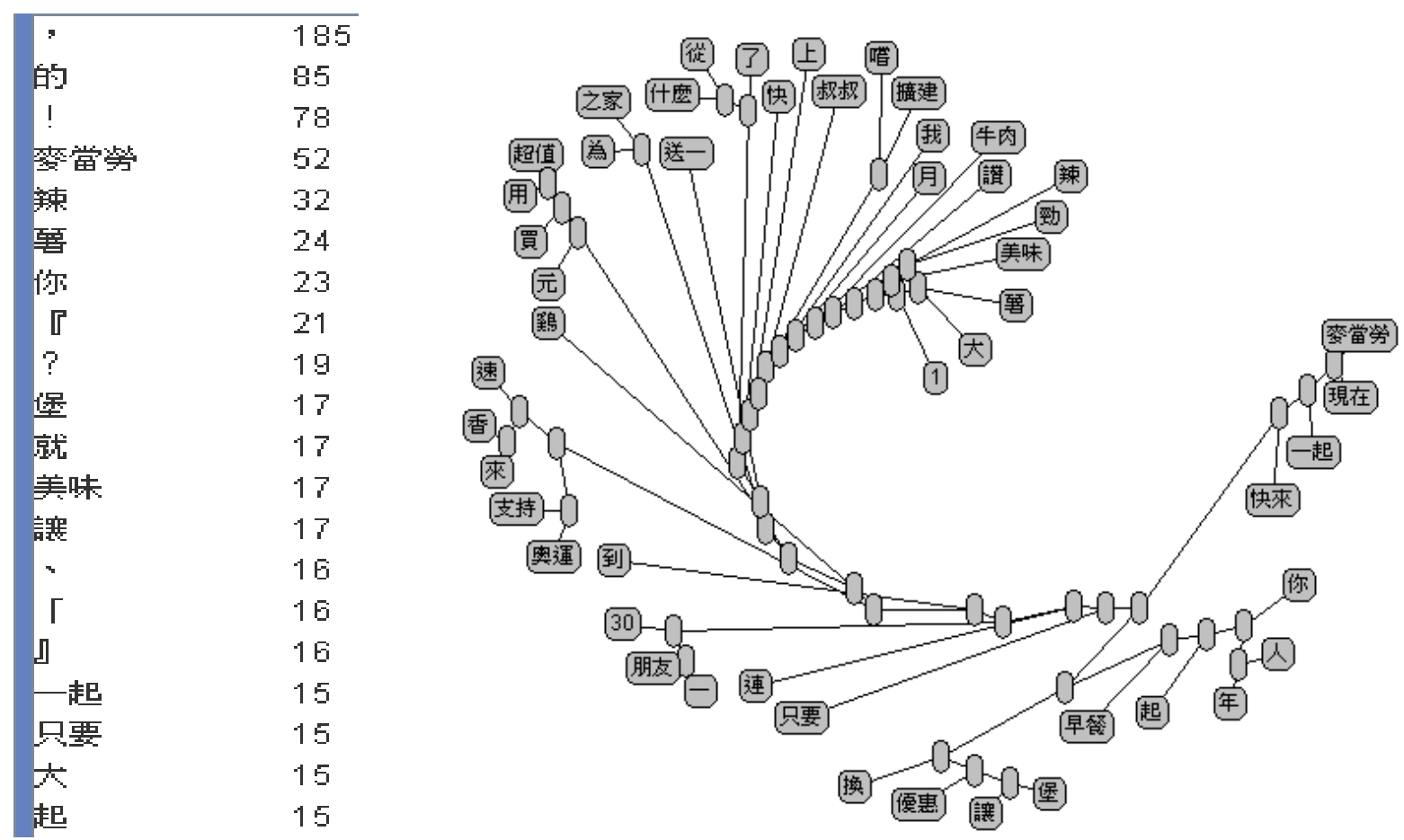

Figure 2. Wolpak outputs of Taiwanese operators from January to June. 


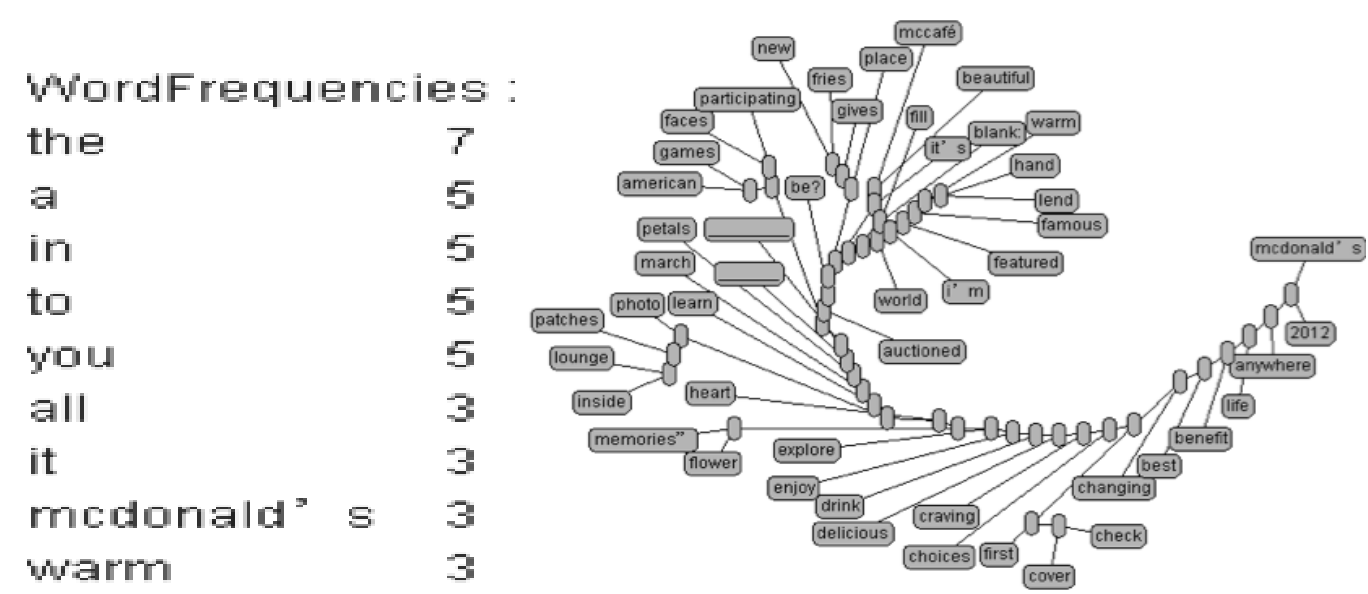

Figure 3. Wolfpak outputs of American operators from January to June.

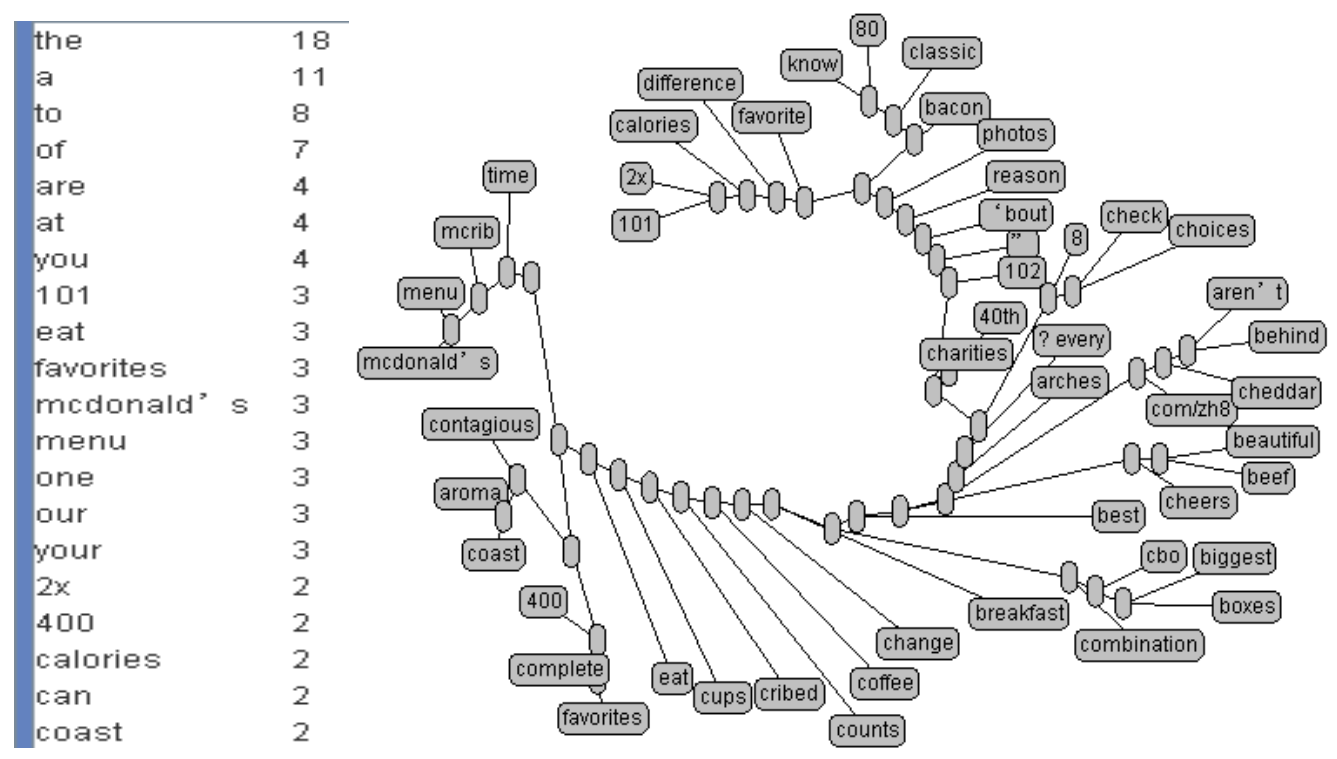

Figure 4. Wolfpak outputs of American operators from July to December.

\subsection{Site Operators' Postings}

From the site operators' postings, although the consistent theme of the content of Facebook postings throughout the whole year of 2012 was marketing, regardless of cultural context, some differences emerged from the results of semantic network analysis. First, Taiwanese site operators used the term "McDonald's" (mài dāng láo) more often than American site operators. Of all the 80 postings written by Taiwanese site operators, Wolfpak detected the use of "McDonald's" 79 times, indicating an almost 100 percent usage of the term; one use per posting. However, of all the 34 postings written by American site operators, Wolfpak detected the use of "McDonald's" only 6 times, indicating a 9 percent usage of the term (Figures 1-4).

For example, Taiwanese operator posted on January 13th:

"nián jiē făn xiāng, sāi chē sāi dào dù zǐ è !! ! dào mài dāng láo dé lái sù, xiăng shòu měi shí chāo fāng biàn ! xiàn zài shǒu jī xià zăi 『dăo háng wáng $\mathrm{APP} 』$, bù dàn qīng sòng zhăo dào mài dāng láo dé lái sù, hái kě xiăng yǒu dé lái sù V I P zhuān shǔ yōu huì !" (The shaded area was added by this author.) (New Year returns, traffic jam makes people hungry!!! Go to McDonald’s drive-thru, enjoy the super convenient food! Download the "navigation Wang APP” now. Not only is it easy to find McDonald's drive-thru, but you can also enjoy exclusive VIP offers!)

Second, Taiwanese site operators incorporated the function provided by Facebook of "Likes" (àn zàn) into the 
content of the postings to instigate interactions from fans, for example, on March 17th:

"mài dāng láo 8 hào cān, yóu nǐ jué dìng shuí dāng jiầ! 『jìn là jī tuǔ băo』 zàn shí xiăn sheng, xiăng ràng『fã shì tián yuán jī tuǐ băo』fān pán...zuì hòu jī huì kuài lái àn zàn, yóu nǐ jué ding! (It is up to you to decide what’s going to be the 8th McDonald's meal! 'King spicy chicken burger' has a temporary lead, want to give 'French countryside chicken burger' a comeback? Last chance to vote by pressing 'Like'!).”

In contrast, the American site operators never used this function to encourage interactions from fans; instead they used the fill in the blank trick. For example, on May 16th:

"Fill in the blank: Today I'm craving from McDonald's."

Third, Taiwanese site operators not only used the term "share" (fên xiăng) 7 times more often than the American site operators, but they also used the term differently from that of American site operators. Taiwanese site operators used "share" when promoting activities or to encourage involvement with fans. For example, on January 21st:

“... jīn huáng sū nèn de 20 kuài mài kè jī kuài dā pèi 2 bēi yǐn liào, kuài lè fền xiăng cān zhī yào $\$ 199$ !"'(20 Golden crisp tender chicken nuggets with 2 drinks, happy to share meals for only \$199!).

Yet, American site operators only used the term "share" once, but used it to suggest NOT sharing; emphasizing the bargain of the meal. The post was written on September 18th:

"Extra Value Menu: Sharing not mandatory. At this price, they can get their own."

Fourth, McDonald's Facebook operators used different words to refer to themselves. American Facebook site operators usually referred to themselves as "we”, “us” or "our”, while Taiwanese Facebook site operators would refer to themselves as "xiăo biān" (little editors). For example:

“jīn nián dà jiā zuì qī dài nă wèi zhōng huá jiàn ér de biăo xiàn ne? kuài lái gēn xiăo biān fēn xiăng bā! (July 18th)(Which athlete's performance are you most looking forward to this year? Come and share it with little editors.)

American Facebook site operators wrote:

"Our very own Chef Dan made an appearance on Good Morning America this morning (September 5th).

Fifth, Taiwanese site operators often market their products with the direct and hard approach, which emphasizes the use of direct and confrontational appeals in forms of discounts and sale promotions [11] [17], with the words such as super value (chāo zhí), great value (yōu huì), half-price (bàn jià), coupons (yōu huì quàn), and buy one get one free (măi yī sòng yī). Also, Taiwanese operators tended to specifically indicate the price of their products (mài cuì jī zhī yào $+\$ 29$ ) to market their products. For example:

"2012 xīn nián xīn xî̀ wàng ... mài dāng láo bāng nǐ măn zú yuàn wàng, xiàn zài tuī chū jīng shěng yōu huì quàn, shǔ bǐng măi yī sòng $y \overline{1}$ 、 mài cuì jī zhī yào $+\$ 29$, dà mài kè chāo zhí quán cân bàn jià... xiàn qî yōu huì, qiān wàn yào bă wò!'(2012 New Year! New Wishes! McDonald's helps you to fulfill your new wishes. We provide coupons, buy one get one potato cake, wheat crispy chicken only $+\$ 29$, half-price Big Mac value meal ... limited time offers, be sure to grab one!) (January $7^{\text {th }}$ ).

Compared with the direct and hard-sell approached adopted by the Taiwanese site operators, the American McDonald's site operators sell their products in a more indirect and soft way, which emphasizes a more suggestive and a softer emotional appeal with the focus on emotions, sentiments and entertainment [11] [17]. For example, they described their French fries as "Golden rays of light" (posted on July 7th), and promoted their company products writing "Falling for the Golden Arches" (posted on November 17th). Or the American site operators would promote their products with a current sporting event, such as "Get off the sidelines \& tackle the favorite meal of the NFL.www.mcdonalds.com/mcnuggets” posted on December $5^{\text {th }}$; or with celebration of a product's birthday such as, "Happy 40th to the Egg McMuffin, the original \& best breakfast classic!" (September 29th).

\subsection{Fans' Postings}

First, when referring to themselves, American fans used words such as "I", "me", and "my" 8.5 times more often (3497 times) than Taiwanese fans (413 times); whereas the total amount of postings written by American fans was 5.3 times greater than Taiwanese fans. For example, on the American Facebook site:

"I'm tempted to try those chicken bites with double cheeseburgers." (January 27th).

"I don't want you to change! I like having a non-healthy meal once in a while. It's not McD's job to police what \& how people eat.” (April 10th). 
“Def Cooley Maroon I love Mcdonald’s! I leave it out for 2 weeks and it's still delicious....” (September 23rd).

"Hi McDonald's I need to share a very important message to you, but unfortunately your message option is closed.” (December 7th).

Second, Taiwanese fans tended to use superlatives such as super (chāo, 43 times), or really (zhen, 41 times) to discuss the prices or the quality of the products more than American fans did (super, 30 times, really 0 times). It is suggested that use of superlatives is common in a more direct communication style [11], [17], [39].

For example:

"chāo guì". (Super expensive, posted on February 1st).

“qián jǐ tiān măi sì kuài mài kè jī kuài sòng kě lè jìng rán yào 55 yuán $==\ldots$ zhī qián măi yào 50 yuán jiù chāo guì de liăo... hái zhăng jià = = nà sì kuài shì yǒu méi yǒu zhè me yāo shòu ā"(just a few days ago, it cost 55 dollars to buy four pieces of chicken nuggets with cola, 50 dollars is expensive enough, they raise the price, god damn, posted on April 17th).

“yǒu kàn cuò ma@@ @ 1288 guì sǐ liăo" (was I mistaken? 1288, super expensive, posted on October 28th).

Third, Taiwanese fans tend to complain more than American fans. When complaining, they talked about how expensive (guì, 27 times) the food is or that the service sucks (lan, 53 times). Also, Taiwan fans used terms such as employees (diàn yuán) or managers (jīng lǐ or diàn zhăng) more often than American fans to express their dissatisfaction with McDonald's products or services.

For example:

“...xià lóu gēn diàn yuán făn yīng, diàn yuán zhī shì shuō shēng SORRY, páng biān de diàn zhăng hái shì diàn jīng lǐ tīng dào lián fãn yīng dōu méi yǒu , zhēn shì lā jī măn gŭ , diàn jīng lǐ wén xùn bù dòng rú shān yā!” (I went downstairs to complain to the employee, he just says sorry. The manager next to me did not say anything. This place is really dirty and has garbage everywhere. And the manger says nothing. (Posted on May 19th).

"yǒu méi yǒu găo cuò shēn wéi jīng lǐ lián fú wù tài dù dōu bù zhī dào, zhè yăng kě yǐ dāng jīng lǐ wō nǐ men píng jiàn méi wèn tí ma???” (Being a manager, do you know at all about good service attitude toward your customers? With your attitude? Are you sure your store could pass the evaluations? (Posted on November 10th).

In contrast, American fans used more positive terms such as "love", "like" or "good" to describe their experience with McDonald's products or services.

For example:

"I like the fries, but my favorite thing made of potato are the potato wedges" (August 29th).

"Love the Big Mac!!” (September 23rd).

"Yes, I like Mcdonald’s every Sunday I eat my breakfast, lunch and dinner because the price is not very expensive that's why my friend and I choose McDonald's” (December 6th).

Finally, American fans pay more attention to the health-related issues than Taiwanese fans resulting from eating McDonald's food, thus they used the words "health" (48 times) and "fat" (109 times) more than Taiwanese fans ("health" 4 times, "fat" 3 times).

"This is why most Americans are very, very fat.” (March 21st).

"You make people fat." (April 10th).

"Golden fats delight." (July $7^{\text {th }}$ ).

"Watch the documentary that defends McDonald’s called FAT HEAD.” (September 23rd).

"McDonald’s is Greasy and Fat, Team Not wanting to gain unwanted fat!" (November 9th).

“Encouraging people to get fatter and fatter. No thanks.” (December 4th).

\section{Discussion}

In general, this study found support for cultural differences in terms of word usages on McDonald's Facebook sites between Taiwan and the USA from the cultural dimension of collectivism and individualism. It appeared that Taiwanese site operators used words such as "share" and "xiăo biān", and utilized Facebook functions such as "likes" to encourage in-group interaction; while American fans used words such as "I" and paid more attention to health-related issues. Other findings about word uses from the current study might be accounted for by two other cultural dimensions suggested by Hofstede: masculinity and femininity, and power distance. Below, the overall findings from the three perspectives are discussed: collectivism and individualism, masculinity and femininity, and power distance. 


\subsection{Collectivism and Individualism}

Hofstede (2001) suggested that individuals raised in a collectivistic culture tend to be integrated from birth into cohesive groups that protect them in exchange for loyalty [13]. Thus, individuals tend to have a high concern for others and prefer to be situated in an environment where they feel belonged and integrated. To carry over the sense of belongingness and integratedness, Taiwanese Facebook site operators, accordingly, would encourage fans to give "likes" to postings, facilitating an environment of supportive interactions among fans and the company. This supportive environment facilitated and maintained on Facebook fan sites would eventually become a forum, place, or club where fans could share their concerns, views and emotions [17] [29] [40]. It is interesting to note that Taiwanese site operators use "likes", while American site operators use "fill in the blanks" to encourage fans' participation. Previous studies have suggested that individuals raised in a collectivistic culture are passive communicators who talk less and disclose less than those in an individualistic culture [27]. Therefore, the action of giving "likes" is the most appropriate integration method to accommodate the communication style of Taiwanese fans. By simply pressing a key to give "likes", Taiwanese fans can find a forum, a place or a club to be emotionally dependent on.

This intent of interaction and integration was also manifested on the Facebook sites by Taiwanese site operators' uses of the word "share”, creating a "we” consciousness by extending connections among fans [13]; the "we" consciousness results in the growth of an interdependent self which facilitates the dynamic process of developing a network of relationships [14].

In addition, Taiwanese site operators used "little editors" to refer to themselves, a common expression of site operators in Taiwan. The word "little" in little editors does not mean the size of an object or a person; rather in Chinese culture, it implies that a humble position was taken when saying or using this term to refer to him/herself. In this case, when used on a Taiwan McDonald's Facebook site, they are referring to the site operators who speak for Taiwan McDonald’s. Compared with the term “we”, used by the American Facebook site operators to refer to themselves, the term "little" implies a value of the self-critical and self-improving orientation in Asian culture [41]. Lee and Park (2011) examined the usage of speech acts across different cultures, particularly in favor asking situations [41]. They found that Confucianism, which assumes that the "self is fundamentally flawed and so modesty is emphasized, and good behavior toward others” (p. 128), might explain why Koreans more frequently include apologies in favor-asking messages [41]. Accordingly, the different needs for positive self-regard may explain why "we" was used to refer to the USA site operators, while "little editors" was used to refer to Taiwanese site operators. As mentioned earlier, the development of self concept is deeply related to the individualism/collectivism dimension of culture [13]. Individuals who have grown up in a collectivistic culture context are used to a "we-group" identity, and may exhibit a strong a desire to build relationships with people around them. Yet, individuals who have grown up in an individualistic culture context only care for their immediate family, and may exhibit a weaker desire to build relations with others. The humble position taken by the Taiwanese Facebook site operators may indicate a desire to build relationships with every potential McDonald's consumer, which is a concept deeply rooted in the cultural dimension of individualism/ collectivism.

Moreover, the current results demonstrate how the individualism and collectivism dimension is penetrated into the work situation as well. Taiwanese site operators used the term "McDonald's" in almost every posting they wrote. It seems that as McDonald's employees, Taiwanese site operators are constantly aware of their working status and see themselves as integral parts of a group. They "act in the interest of the organization they are employed by, not of themselves” ([13], p. 8]). In contrast, employees in an individualistic culture are expected to work rationally as individuals with their own interests and needs. The relationship between employer and employee can clearly be seen from two other cultural dimensions: power distance and masculinity/femininity.

\subsection{Power Distance}

The power distance dimension describes the degree of how people accept hierarchical structures and acceptance of and dependence on the authority of more powerful people [13]. Taiwan, compared with the USA, belongs to a high power distance culture, which indicates that Taiwanese people are more willing to accept inequality in power distribution. As a result, Taiwanese site operators always mentioned "McDonald's" to show respect to the authority in the hierarchy, displaying a stricter relationship between superiors and subordinates.

The acceptance of dependence on people with power is not only just manifested in the work situation between employees and employers; it is also accepted by individuals raised in collectivistic cultures in general as well. 
The results suggest that when McDonald's Taiwanese fans complained, they used the terms “employees” and "managers" a lot. It appears that Taiwanese fans faced with unsatisfactory situations would resort to and rely on the people who are in an appropriate level in the hierarchical structure to use power to solve the problematic situations. In a culture characterized with acknowledgement of inequality in power distribution, it is not uncommon to expect an authority person with power to take the lead.

\subsection{Masculinity and Femininity}

This dimension deals with the implications that the biological differences between the sexes should have for the social role of the genders [13]. Masculine roles attach more importance to ego goals, emphasizing assertiveness, competition, and toughness; feminine roles attach more importance to social goals, focusing on relationships, people, and tenderness [13] [42]. Based on the division of emotional roles between men and women, masculine cultures emphasize money and materialism and have a stronger differentiation between gender roles; that is, the values of females and males are very different. Whereas feminine cultures emphasize quality of life and human interaction and have a weaker differentiation between gender roles; that is, the values of females and males are hardly different [13].

According to Hofstede's study, the mean score of masculinity is 49. The score of Taiwan was 45 and the score of the USA was 62, indicating that the USA has a higher degree of masculinity than that of Taiwan. However, the current study revealed that Taiwanese fans discussed and complained about the prices of McDonald's products using strong words such as "sucks" and "sucks to death" more than USA fans; whereas USA fans paid more attention to the health-related topics using words such as "fat" and "fatty" more than Taiwanese fans. It seems that Taiwanese fans "live in order to work", focusing more on money, a characteristic of a masculine culture; yet USA fans “work in order to live”, emphasizing quality of life. The philosophy, "live in order to work”, could also account for the reasons that Taiwanese site operators wrote the word "McDonald's" in almost every one of the postings they wrote. To Taiwanese people, what you do is more important than who you are [13]. Since, work plays a very central role in individuals' life space; it is not surprising that Taiwanese employees would mention the company they worked for all the time.

The other finding from the current study suggesting that Taiwanese culture is more towards masculinity on the continuum of masculinity/femininity dimension is the hard-sell approach used by Taiwanese site operators. Taiwanese site operators often used direct and explicit words such as discounts, promotions and coupons to deliver their products, indicating the value of assertiveness, success and performance emphasized in masculine culture [11]. Actually, the findings suggesting that Taiwan is a more masculine culture than Hofstede's original categorization is not a new issue. Chang and Tseng (2009) had a similar observation when comparing the content and web design of social network sites between Taiwan and USA [36].

\subsection{Limitations}

The major limitation of the current study is technical. The study used Wolfpak to perform semantic network analysis on all the postings from Taiwan and the USA because it is the only semantic network analysis software with the technical ability to read Chinese and English characters at the same time. However, three major problems were encountered during the process of analyzing the data. First, it appears that Wolfpak can identify individual Chinese character, yet it has a problem accurately deciphering Chinese terms consisting of more than one word. For example, the term "little editors" consists of two individual Chinese characters, "xiăo" and "biān". Wolfpak read the term as two individual words. The term "buy one get one free" consists of four individual

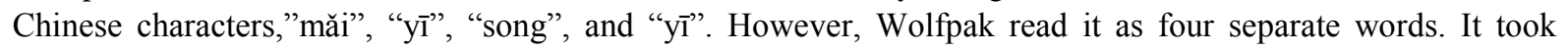
plenty of human effort to compensate for Wolfpak's inability to make an accurate judgment of Chinese terms. The second problem with Wolfpak is that it only detects word clusters based on the occurrence of words' frequency. However, "relations among words are identified by distance, co-occurrence, and frequency” ([35], p. 17). Future study should rely more on software that can analyze the relations among words when distance and co-occurrence of words can be calculated. Lastly, when calculating word frequencies, although the program has the function to exclude words such as conjunction words, it is only calculated in the graphical connection of words, not the word frequency chart (left part from Figure 1 through 4). Basically, Wolfpak calculated every word in a given text to produce the output of word frequencies, with no excluding function at all. 


\subsection{Conclusion}

The study is the first attempt to examine cultural differences of language used on corporate Facebook sites between Taiwan and the USA through semantic network analysis. In general, the study found support for cultural differences through word usage from official McDonald's Facebook site operators and fans between Taiwan and the USA. It appeared that Taiwanese Facebook culture is characterized with the creation of a "we-identity”, with dependence more on people in authority, and a focus on money and materialism; whereas American Facebook culture is characterized with an "I-identity", with less dependence on people in authority, and more focus on self-interests. As mentioned earlier, attracting Facebook fans is potentially important marketing strategy worldwide [43], the results of the present paper suggested that multinational corporation should utilize different marketing communication strategies in different cultural contexts. Due to limited resources, only one year of postings each month was studied from one corporate's Facebook sites in two countries. Future studies may benefit from extending the research design in time, population and environments [44].

\section{References}

[1] Kim, Y., Sohn, D. and Choi, S.M. (2011) Cultural Difference in Motivations for Using Social Network Sites: A Comparative Study of American and Korean College Students. Computers in Human Behavior, 27, 365-372. http://dx.doi.org/10.1016/j.chb.2010.08.015

[2] Solis, B. and Breakenridge, D.K. (2009) Putting the Public Back in Public Relations: How Social Media Is Reinventing the Aging Business of PR. FT Press, Upper Saddle River.

[3] Zhang, L., Tian, S. and Miles, P.C. (2014) Content and Design Characteristics of Chinese and US Corporate Homepages. International Journal of Electronic Business, 11, 153-175. http://dx.doi.org/10.1504/IJEB.2014.060208

[4] Cyr, D. (2008) Modeling Web Site Design across Cultures: Relationships to Trust, Satisfaction, and E-Loyalty. Journal of Management Information Systems, 24, 47-72. http://dx.doi.org/10.2753/MIS0742-1222240402

[5] Cyr, D. and Trevor-Smith, H. (2004) Localization of Web Design: An Empirical Comparison of German, Japanese, and United States Web Site Characteristics. Journal of the USA Society for Information Science and Technology, 55, 1199-1208. http://dx.doi.org/10.1002/asi.20075

[6] Singh, N., Toy, D.R. and Wright, L.K. (2009) A Diagnostic Framework for Measuring Web-Site Localization. Thunderbird International Business Review, 51, 281-95. http://dx.doi.org/10.1002/tie.20265

[7] Shannon, P. (2000) Including Language in Your Global Strategy for B2B E-Commerce. World Trade, 13, 66-68.

[8] Baack, D.W. and Singh, N. (2007) Culture and Web Communications. Journal of Business Research, 60, 181-88. http://dx.doi.org/10.1016/j.jbusres.2006.11.002

[9] Chang, H.J. (2011) Multinationals on the Web: Cultural Similarities and Differences in English-Language and Chinese-Language Website Designs. Journal of the American Society for Information Science and Technology, 62, 11051117. http://dx.doi.org/10.1002/asi.21515

[10] Daryanto, A., Khan, H., Matlay, H. and Chakrabarti, R. (2013) Adoption of Country-Specific Business Websites: The Case of UK Small Businesses Entering the Chinese Market. Journal of Small Business and Enterprise Development, 20, 650-660. http://dx.doi.org/10.1108/JSBED-04-2013-0048

[11] Singh, N. and Matsuo, H. (2004) Measuring Cultural Adaptation on the Web: A Content Analytic Study of US and Japanese Web Sites. Journal of Business Research, 57, 864-872. http://dx.doi.org/10.1016/S0148-2963(02)00482-4

[12] Yalcin, S., Singh, N., Dwivedi, Y.K., Apil, A.R. and Sayfullin, S. (2011) Culture and Localization on the Web: Evidence from Multinationals in Russia and Turkey. Journal of Electronic Commerce Research, 12, 94-114.

[13] Hofstede, G. (2001) Culture’s Consequences: International Differences in Work-Related Values. Sage, Newbury Park.

[14] Ting-Toomey, S. (1999) Communicating across Cultures. Guiford Press, New York.

[15] Miniwatts Marketing Group (2014) Internet World Users By Language: Top 10 Languages. http://www.Internetworldstats.com/stats7.htm

[16] Kang, D.S. and Mastin, T. (2008) How Cultural Difference Affects Inter-National Tourism Public Relations Websites: A Comparative Analysis Using Hofstede’s Cultural Dimensions. Public Relations Review, 34, 54-56. http://dx.doi.org/10.1016/j.pubrev.2007.11.002

[17] Moura, F.T., Gnoth, J. and Deans, K.R. (2014) Localizing Cultural Values on Tourism Destination Websites: The Effects on Users' Willingness to Travel and Destination Image. Journal of Travel Research, 1-15. http://dx.doi.org/10.1177/0047287514522873

[18] Usunier, J.C., Roulin, N. and Ivens, B.S. (2009) Cultural, National, and Industry-Level Differences in B2B Web Site 
Design and Content. International Journal of Electronic Commerce, 14, 41-88. http://dx.doi.org/10.2753/JEC1086-4415140202

[19] Würtz, E. (2005) A Cross-Cultural Analysis of Websites from High-Context Cultures and Low-Context Cultures. Journal of Computer-Mediated Communication, 11, 274-299. http://jcmc.indiana.edu/vol11/issue1/wuertz.html http://dx.doi.org/10.1111/j.1083-6101.2006.tb00313.x

[20] Gudykunst, W.B., Matsumoto, Y., Ting-Toomy, S., Nishida, T., Kim, K. and Heyman, S. (1996) The Influence of Cultural Individualism-Collectivism, Self Construals, and Individual Values on Communication Styles across Cultures. Human Communication Research, 22, 510-543. http://dx.doi.org/10.1111/j.1468-2958.1996.tb00377.x

[21] Gevorgyan, G. and Manucharova, N. (2009) Does Culturally Adapted Online Communication Work? A Study of USA and Chinese Internet Users' Attitudes and Preferences toward Culturally Customized Web Design Elements. Journal of Computer-Mediated Communication, 14, 393-413. http://dx.doi.org/10.1111/j.1083-6101.2009.01446.x

[22] Boase, J. and Ikeda, K.I. (2012) Core Discussion Networks in Japan and America. Human Communication Research, 38, 95-119. http://dx.doi.org/10.1111/j.1468-2958.2011.01416.x

[23] Gudykunst, W.B. and Matusmoto, Y. (1996) Cross-Cultural Variability of Communication in Personal Relationships. In: Gudykunst, W.B., Ting-Toomy, S. and Nishida, T., Eds., Communication in Personal Relationships across Cultures, Sage, Thousand Oaks, 19-56.

[24] Markus, H.R. and Kitayama, S. (1991) Culture and the Self: Implications for Cognition, Emotion, and Motivation. Psychological Review, 98, 224-253. http://dx.doi.org/10.1037/0033-295x.98.2.224

[25] Triandis, H.C. (1995) Individualism \& Collectivism. Westview Press, Boulder.

[26] Hall, E.T. (1976) Beyond Culture. Doubleday, New York.

[27] Kim, H., Coyle, J.R. and Gould, S.J. (2009) Collectivist and Individualist Influences on Website Design in South Korea and the US: A Cross-Cultural Content Analysis. Journal of Computer-Mediated Communication, 14, 581-601. http://dx.doi.org/10.1111/j.1083-6101.2009.01454.x

[28] Robbins, S.S. and Stylianou, A.C. (2002) A Study of Cultural Differences in Global Corporate Web Sites. Journal of Computer Information Systems, 42, 3-9.

[29] Singh, N. and Baack, D.W. (2004) Web Site Adaptation: A Cross-Cultural Comparison of US and Mexican Web Sites. Journal of Computer-Mediated Communication, 9. http://jcmc.indiana.edu/vol9/issue4/singh_baack.html http://dx.doi.org/10.1111/j.1083-6101.2004.tb00298.x

[30] De Andrea, D.C., Shaw, A.S. and Levine, T.R. (2010) Online Language: The Role of Culture in Self-Expression and Self-Construal on Facebook. Journal of Language and Social Psychology, 29, 425-442. http://dx.doi.org/10.1177/0261927X10377989

[31] Doerfel, M.L. and Connaughton, S.L. (2009) Semantic Networks and Competition: Election Year Winners and Losers in US Televised Presidential Debates, 1960-2004. Journal of the USA Society for Information Science and Technology, 60, 201-218. http://dx.doi.org/10.1002/asi.20950

[32] Fitzgerald, G.A. and Doerfel, M.L. (2004) The Use of Semantic Network Analysis to Manage Customer Complaints. Communication Research Reports, 21, 231-242. http://dx.doi.org/10.1080/08824090409359985

[33] Doerfel, M.L. and Barnett, G.A. (1999) A Semantic Network Analysis of the International Communication Association. Human Communication Research, 25, 589-603. http://dx.doi.org/10.1111/j.1468-2958.1999.tb00463.x

[34] Kim, J.H. (2012) A Hyperlink and Semantic Network Analysis of the Triple Helix (University-Government-Industry): The Interorganizational Communication Structure of Nanotechnology. Journal of Computer-Mediated Communication, 17, 152-170. http://dx.doi.org/10.1111/j.1083-6101.2011.01564.x

[35] Lee, S., Kim, H. and Rosen, D. (2009) A Semantic Network and Categorical Content Analysis of Internet and Online Media Research. The Open Communication Journal, 3, 15-28. http://dx.doi.org/10.2174/1874916X00903010015

[36] Chang, H.J. and Tseng, I. (2009) A Cross-Cultural Analysis of Social Network Sites in Taiwan and USA: A Comparison between Wretch and My Space. Journal of Electronic Business, 11, 611-638. (In Chinese)

[37] Kim, K.-H. and Yun, H. (2008) Cying for Me, Cying for Us: Relational Dialectics in a Korean Social Network Site. Journal of Computer-Mediated Communication, 13, 298-318. http://dx.doi.org/10.1111/j.1083-6101.2007.00397.x

[38] Borgatti, S.P., Everett, M.G. and Freeman, L.C. (2002) Ucinet for Windows: Software for Social Network Analysis. Analytic Technologies, Harvard.

[39] Caillat, Z. and Mueller, B. (1996) The Influence of Culture on American and British Advertising: An Exploratory Comparison of Beer Advertising. Journal of Advertising Research, 36, 79-88.

[40] Callahan, E. (2005) Cultural Similarities and Differences in the Design of University Web Sites. Journal of ComputerMediated Communication, 11, 239-273. http://dx.doi.org/10.1111/j.1083-6101.2006.tb00312.x 
[41] Lee, H.E. and Park, H.S. (2011) Why Koreans Are More Likely to Favor “Apology,” While Americans Are More Likely to Favor “Thank You”. Human Communication Research, 37, 125-146. http://dx.doi.org/10.1111/j.1468-2958.2010.01396.x

[42] Marcus, A. and Gould, E.W. (2000) Cultural Dimensions and Global Web User-Interface Design. Interactions, 7, 3346. http://dx.doi.org/10.1145/345190.345238

[43] Wallace, E., Buil, I., de Chernatony, L. and Hogan, M. (2014) Who Likes You and Why? A Typology of Facebook Fans. Journal of Advertising Research, 54, 92-109. http://dx.doi.org/10.2501/JAR-54-1-092-109

[44] Cook, T.D., Campbell, D.T. and Day, A. (1979) Quasi-Experimentation: Design \& Analysis Issues for Field Settings (Volume 351). Houghton Mifflin, Boston. 